\title{
Factors Contributing to Academic Performance of Students in a Tertiary Institution in Singapore
}

\author{
S. Valli Jayanthi ${ }^{1}$, Santhi Balakrishnan ${ }^{1}$, Angela Lim Siok Ching ${ }^{2}$, Noor Aaqilah Abdul Latiff ${ }^{1}$, A.M.A. Nasirudeen ${ }^{1, *}$ \\ ${ }^{1}$ School of Health Sciences, Ngee Ann Polytechnic, 535 Clementi Road, Singapore \\ ${ }^{2}$ Alexandra Hospital-Jurong Health Services, 378 Alexandra Road, Singapore \\ *Corresponding author: anm2@np.edu.sg
}

Received July 05, 2014; Revised August 09, 2014; Accepted August 27, 2014

\begin{abstract}
This study was conducted to examine different factors influencing the academic performance of students in a tertiary institution in Singapore. The main method of data collection was a semi-structured questionnaire administered to 144 students. The specific objectives of the study were to determine if factors such as gender, age, nationality of student, part-time employment, extracurricular activities and interest in pursuing higher studies affected academic success. The study also examined the learning methods used by students and how these affected their academic scores. The students' cumulative Grade Point Average (cGPA) was used as a measure of academic performance. The data were analyzed quantitatively and the results showed that factors such as gender, nationality of student, co-curricular activities and an interest in pursuing higher degrees affected students' academic scores. The use of past year examination papers as a learning method improved students' academic scores compared to other methods.
\end{abstract}

Keywords: school education, academic performance, tertiary institution, Singapore education, Singapore students

Cite This Article: S. Valli Jayanthi, Santhi Balakrishnan, Angela Lim Siok Ching, Noor Aaqilah Abdul Latiff, and A.M.A. Nasirudeen, "Factors Contributing to Academic Performance of Students in a Tertiary Institution in Singapore.” American Journal of Educational Research, vol. 2, no. 9 (2014): 752-758. doi: 10.12691/education2-9-8.

\section{Introduction}

Academic success has a great influence on a student's self-esteem, motivation, and perseverance in higher education. Poor academic performance or high failure rates may result in unacceptable levels of attrition, reduced graduate throughput and increased cost of education. This also reduces admission opportunities for tertiary students seeking higher degrees. Hence, students' academic performance has always been a topic of interest for educators. Educators and researchers have long been interested in identifying and understanding the variables that contribute to academic excellence. Many researchers have identified demographic, socio-economic, family and school factors as variables contributing to students' academic performance [1,2].

Academic performance according to the Cambridge University Reporter [3] is frequently defined in terms of examination performance. In this study academic performance was characterized by the overall performance in each year which culminates in a Grade Point Average (GPA). The GPA score would take into account students' performance in tests, course work and examinations. The method of computing the GPA is as shown below:

$$
\text { Current GPA }=\frac{\text { Sum of (Credit Units x Grade Points) }}{\text { Total number of modules takenby student }}
$$

The minimum and maximum GPA scores are 0 (Grade F) and 4.0 (Grade A) respectively. This GPA score implies that the higher the score, the better the students' had performed academically. As such, the GPA will be a good measure of a students' academic performance.

The students enrolled in any tertiary institute in Singapore may come from various educational backgrounds. However, they are provided the same educational services in the tertiary institute. But some students perform much better than others academically. The researchers are interested to know what makes some students perform well compared to others.

The purpose of this research was to understand the possible causal factors and ways of addressing them so that students' academic performance can be improved. This study aims to contribute to the existing knowledge by documenting the factors associated with students' academic success or failure in a tertiary institute in Singapore.

\section{Literature Review}

Past research studies have identified several factors that affect academic performance of students in various centres of learning. Some of these factors include class attendance [4], age, learning styles or preferences [5], gender [6], class size [7], entry qualifications [8], family income [9], 
etc. This literature review provides a brief examination of some of the factors that have been evaluated in this study.

\subsection{Gender and Academic Performance}

Research done by Borde [10] showed that gender did not play a role in academic performance. Another study by Meece and Jones [11] also revealed that gender differences did not influence students' standardized science test scores.However, Haist et al., [6] showed that men performed better than women in certain settings while women outperformed men in other settings. A study by Hedges and Newell [12] showed male students outperformed female students in science, but in reading and writing female students did much better. However, educational statistics have indicated that female students are outperforming their male counterparts at all levels of the education system and attaining higher qualifications $[13,14]$. After analyzing more than a million graduating students, Woodfield and Earl-Novell [15] observed that female students did better than male students. Woodfield and Earl-Novell [15] attributed this partly to female students being more academically responsible and thus less likely to be absent from lessons.

\subsection{Nationality and Academic Performance}

Several studies have shown that academic performance differs across nationality $[16,17,18]$. A study by Yousef [19] showed that foreign students outperformed local students in business studies. In a study by Nasirudeen et al. [20], it was shown that international students in Singapore experienced substantial levels of stress, which are often a result of homesickness, cultural shocks, or perceived discrimination. This, in turn, may have a negative influence on their participation in activities that contribute to important learning and personal development. One common coping mechanism used by international students is to focus more on academic achievement [21,22]. However, a study by Rienties et al. [23] showed that nonWestern students scored significantly lower on GPA compared to Western students.

\subsection{Students' Learning Styles or Preferences and Academic Performance}

It is believed that learning styles play a small role on academic performance [24,25]. However small the effect on learning outcomes, it is accepted that learning styles can help students enhance their own learning and thus encourage self-directed learning [26]. Fielding [27] showed that it is necessary for students and educational institutions to understand learning styles. Students usually have preferences for the ways by which they learn or understand a subject and it is advisable for students to tailor these styles to suit their own learning needs [28]. As stated by Cuthbert [29], understanding the students' learning styles is important for allowing adjustment in the educators' pedagogic approaches. Several studies [30,31,32] have used standardized tools (such as the Visual, Aural, Read/write and Kinesthetic (VARK) questionnaire [33], Grasha-Reichmann Student Learning Styles survey [34]) to identify and understand the learning preference of their students, but none have looked at the association of student specific preference(s) with academic performance.

\subsection{Other Determinants of Academic Performance}

School students across Singapore participate in a wide variety of extracurricular activities (also known as cocurricular activities). These can be sports, clubs, debate, drama, school publications, student council, and other social events. These activities are, voluntary, usually conducted outside the normal school hours, and students do not receive grades for their involvement [35]. Silliker and Quirk [36] concluded that participation in athletics (such as soccer) for high school students enhances academic performance. Gerber [37] also found that participation in extracurricular activities promoted greater academic achievement. Many extracurricular activities have proven to be beneficial in enhancing academic performance, even if the activities are not obviously related to academic subjects [38]. Students participating in extracurricular activities did better academically than students who did not participate [38].

The concept of academic self-efficacy was devised by Albert Bandura [39]. Self-efficacy concept is defined "A conviction that one can successfully execute the behavior required to produce outcome “(pg. 193). It has been proven that students high in academic self-efficacy set higher academic goals [40].

\subsection{Objectives of the Study}

The main objective of the study was to analyze the effect of gender differences, age, nationality, involvement in extra-curricular activities, part-time employment, and intention to pursue higher studies on students' academic performance.

Null Hypothesis: There is no significant effect of gender, age, nationality, involvement in extra-curricular activities, part-time employment, and intention to pursue higher studies on quality of students' academic performance.

\section{Methods}

A convenient sample of 160 students from a tertiary institute in Singapore was recruited to complete a questionnaire for this study. Usable questionnaires were obtained from 144 students. Table 1 summarises the demographic characteristics of the participants. The research methodology was approved by the institutional review board and all participants provided written informed consent.

The study was conducted using the correlation research design because the study was intended to investigate the relationship between gender, nationality, extra-curricular activities, intention to pursue higher studies and academic performance. According to Fraenkel and Wallen[41], correlation research describes an existing relationship between variables. The study took the quantitative approach because it was based on variables measured with numbers and analyzed with statistical procedures. The questionnaire comprised of mostly two-item scale questions.For the present study, Cronbach's alpha ( $\mathrm{r}=$ 0.71), Spearman-Brown's split half technique $(r=0.89)$ and Guttman's split half technique $(r=0.88)$ all revealed acceptable reliability coefficients.To ensure validity of the 
research instrument, the researchers asked research supervisors in the School of Health Science to validate the questionnaire. The rated findings were used to calculate the content validity of individual items (I-CVI) and the content validity of the overall scale (S-CVI/UA) using the method described by Polit and Beck [42]. The mean I-CVI and S-CVI/UA for the questionnaire used in this study was 0.93 and 0.75 respectively. Kathuri and Palls [43] argue that instruments with validity confident of at least 0.7 are accepted as valid in research.

Written permission to conduct the research was obtained from the director of the school in which the research was conducted. Written and verbal information about the study were given to all participating students. Written consent was sought from the students before administering the survey. The confidentiality of information gathered on the survey form was guaranteed. Individual responses were not reported. Students were also informed that their participation in the study was voluntary and they can withdraw from the study at any time without negative consequences.
Data from the survey were transferred to Microsoft Excel 2010. Standard data entry and quality control procedures were used including double entry, range and consistency checks, and manual review of outliers. All statistical analyses were performed using SPSS software (version 20.0).

\section{Results \& Discussion}

Figure 1 shows a comparison of the mean cGPA for the different variables and Cohen's d was calculated to determine effect size. A study might result in a statistically significant result but have a small effect size and, hence, be considered unimportant [44]. Cohen's $d$ quantifies the magnitude of the difference between populations or the relationship between dependent and independent variables. The meaning of effect size varies by context, but the standard interpretation offered by Cohen [45] is:0.8 or more = large effect size, $0.5=$ moderate effect size and 0.2 $=$ small effect size.

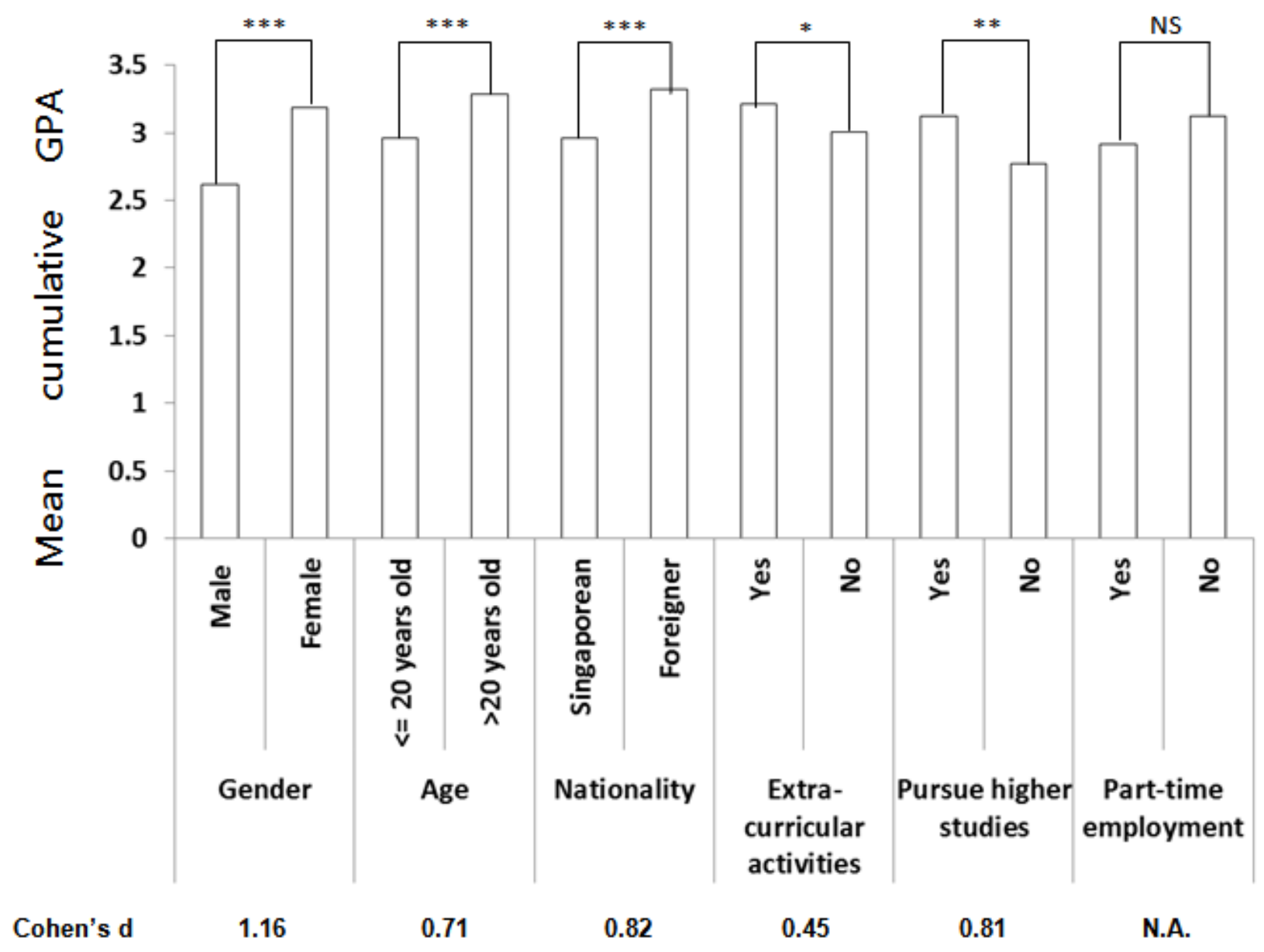

Figure 1. Graphical representation of mean cumulative GPA and variables

\footnotetext{
*** $\mathrm{p}<0.001$ (2 tailed), ** $\mathrm{p}<0.01$ level (2-tailed), ${ }^{*} \mathrm{p}<0.05$ level (2-tailed), NS (Not significant).
}

Linear regression analysis (Table 2) revealed the value of $\mathrm{R}^{2}$ as approximately $37 \%$. This shows that $37 \%$ variations in academic performance can be attributed to gender, age, nationality, ECA and intention to pursue higher studies.

\subsection{Gender Differences and Academic Performance}

There were 119 females (82.6\%) compared to 25males (17.4\%) who participated in this study. Table 1 illustrates the data regarding gender of the respondents.

Figure 1 illustrates that an independent t-test analysis revealed female students had higher cGPA scores than the scores of their male counterparts. Female students had a statistically significant higher mean cGPA score $(\mathrm{m}=$ 3.189) than male students $(m=2.616)$. Apart from the 
statistical differences between the cGPAs of female students and male students, Cohen's $d(d=1.16)$ revealed a large effect size indicating a meaningful statistical difference.

In Table 2, the coefficients of Female (Gender) show that test score will increase by 0.508 units if the student is female, holding other factors constant. This coefficient is very highly significant with a $p$ value less than 0.001 . The null hypothesis that there is no significant difference in the quality of academic performance of students in relation to their gender is therefore rejected.

The findings of this study are in agreement with several other studies. Studies have indicated that gender plays a part in the student academic achievement. Previous studies have shown female students performing better academically than males $[2,46,47,48]$. Leonard and Jiang [47] suggest that females have better study skills than their male counterparts. Wainer and Steinberg [49] believe that female students perform academically better than males because they work harder and attend class more frequently. However, other studies have shown that gender had minor impacts upon academic performance and gender differences exist depending on subject matter $[6,50]$.

Table 1. Characteristics of the sample, $n=144$

\begin{tabular}{lcc}
\hline Socio-Demographic characteristics & $\mathrm{n}$ & $\%$ \\
\hline Gender & 25 & 17.4 \\
$\quad$ Male & 119 & 82.6 \\
Female & & \\
Age & 86 & 59.7 \\
$\quad 20$ and below & 58 & 40.3 \\
$\quad$ Above 20 & & \\
Nationality & 92 & 63.9 \\
Singaporean & 52 & 36.1 \\
Foreigner & & \\
Extra-curricular activities (ECA) & 58 & 40.3 \\
$\quad$ Yes & 86 & 59.7 \\
$\quad$ No & & \\
$\quad$ Intention to pursue higher studies & 129 & 89.6 \\
$\quad$ Yes & 15 & 10.4 \\
$\quad$ No & & \\
Part-time employment & 23 & 16.0 \\
Yes & 121 & 84.0 \\
No & & \\
\hline
\end{tabular}

Regression statistics

Table 2. Regression statistics for independent and dependent variables

\begin{tabular}{|c|c|c|c|}
\hline $\mathrm{R}$ & $\mathrm{R}$ Square & Adjusted R Square & Std. Error of the Estimate \\
\hline 0.606 & 0.368 & 0.340 & 0.4020 \\
\hline
\end{tabular}

ANOVA

\begin{tabular}{|l|c|c|c|c|c|}
\hline & Sum of Squares & df & Mean Square & F & Sig. \\
\hline Regression & 12.874 & 6 & 2.146 & 13.277 & 0.000 \\
Residual & 22.141 & 137 & 0.162 & & \\
Total & 35.014 & 143 & & & \\
\hline
\end{tabular}

Coefficients

\begin{tabular}{|c|c|c|c|c|c|c|c|}
\hline & \multicolumn{2}{|c|}{ Unstandardized Coefficients } & \multicolumn{3}{|l|}{$\begin{array}{l}\text { Standardized } \\
\text { Coefficients }\end{array}$} & \multicolumn{2}{|c|}{ 95.0\% Confidence Interval for B } \\
\hline & B & Std. Error & Beta & T stat & P-value & Lower bound & Upper bound \\
\hline (Constant) & 2.279 & 0.127 & & 17.940 & 0.000 & 2.028 & 2.530 \\
\hline Female & 0.508 & 0.091 & 0.391 & 5.594 & 0.000 & 0.329 & 0.688 \\
\hline Age (above 20 years) & 0.070 & 0.039 & 0.139 & 1.775 & 0.078 & -0.008 & 0.148 \\
\hline Foreigner & 0.105 & 0.039 & 0.205 & 2.689 & 0.008 & 0.028 & 0.183 \\
\hline Involvement in ECA & 0.156 & 0.071 & 0.155 & 2.185 & 0.031 & 0.015 & 0.297 \\
\hline Pursue higher studies & 0.238 & 0.112 & 0.147 & 2.127 & 0.035 & 0.017 & 0.458 \\
\hline
\end{tabular}

\subsection{Age and Academic Performance}

In this study, $40.3 \%$ of the students were aged twenty years and above $(n=58)$ while the rest were below twenty years of age $(n=86)$ (Table 1$)$. Older students had a statistically significant higher mean cGPA score $(\mathrm{m}=$ 3.286) than younger students $(m=2.957)$. Cohen's $d(d=$ 0.71 ) revealed a moderate effect size. Coefficient from linear regression analysis was not significant at 5\% level of significance. The null hypothesis that there is no significant difference in the quality of academic performance of students in relation to their age is therefore upheld.

Age might be beneficial but in results its effect is not significant on students' academic performance. Richardson [51] reported that mature students performed well in most academic settings than younger students. Richardson [51] reasoned that mature students seek a deeper understanding of their academic work unlike younger students who may adopt a surface approach.
However, the results obtained in this study shows that although being older in age may lead to better cGPA scores, age does not have a significant impact on academic performance $(p>0.05)$. The results of this study on age and academic performance are in agreement with that of Mlambo [8].

\subsection{Nationality and Academic Performance}

About $36.1 \%$ of students in this study were foreigners or international students (Table 1). Figure 1 illustrates that international students scored better mean cGPA $(\mathrm{m}=3.319)$ compared to Singaporean students $(m=2.960)$. Cohen's d $(d=0.82)$ showed large effect size with a high statistical significance $(\mathrm{p}<0.001)$. Linear regression analysis coefficient showed that cGPA will increase by 0.105 units if the student is a foreigner, holding other factors constant (Table 2). This coefficient is highly significant with a $p$ value less than 0.01 . The null hypothesis that there is no significant difference in the quality of academic 
performance of students in relation to their nationality is therefore rejected.

The international students in this study are from Asian countries such as China, Malaysia, Vietnam, Myanmar and Indonesia. Most of the international students in Singapore are offered scholarships or bursaries to finance their studies in Singapore [20]. Funding agencies keep track of students' performances and decide if scholarships should be continued. As such, international students are highly focused and motivated to do well academically to retain continued funding from their sponsors. Moreover, international students who may have a weak social support system may encounter high levels of acculturative stress [20] and one common coping mechanism is to focus more on academic achievement [21,22].

\subsection{Extra-curricular Activities and Academic Performance}

About $40.3 \%$ of students in this study participated in ECAs and scored statistically significant cGPA ( $\mathrm{m}=$ 3.217) than students who had no ECA $(m=3.003)$ (Figure 1).However Cohen's $d(d=0.45)$ showed a small/moderate effect size with statistical significance $(p<0.05)$. The researchers are of the view that the small/moderate effect size of this group may prevent meaningful comparisons. Linear regression analysis coefficient showed that cGPA will increase by 0.156 units if a student is involved in ECA, holding other factors constant (Table 2). This coefficient is significant with a $p$ value less than 0.05 . The null hypothesis that there is no significant difference in the quality of academic performance of students in relation to their involvement in ECA is therefore rejected.

The results of this study showed that student involvement in ECA led to an improvement in cGPA scores. Fredricks and Eccles [52] found that participation in extra-curricular activities can lead to positive academic outcomes, including improved grades and test scores. According to Gardner et al., [53], participation in such activities is positively associated with educational and civic success in young adulthood.

\subsection{Higher Studies and Academic Performance}

Students who reported an intention in pursuing higher studies performed better (mean cGPA $=3.127$; $n=129$ ) than those who did not (mean cGPA $=2.767 ; n=15$ ) (Table 1 \& Figure 1$)$. Cohen's $d(d=0.81)$ revealed a large effect size. Regression statistics for this relationship gave a coefficient value of 0.238 . This coefficient is significant with a $p$ value less than 0.05 . The null hypothesis that there is no significant difference in the quality of academic performance of students in relation to their intention to pursue higher studies is therefore rejected.

Most of the students (89.6\%) who participated in this study have the intention to pursue higher studies after graduation. Zimmerman et al., [40] showed that students with high academic self-efficacy set higher academic goals and willingly choose more challenging academic tasks [54].

\subsection{Students' Learning Styles or Preferences and Academic Performance}

The mean cGPA scored by students when they used at least one of the six learning preferences was compared and presented in Table 3. Students who included "Practice past year exam papers" as one of their learning preferences scored better cGPA $(\mathrm{m}=3.218)$ compared to those who did not $(m=2.946)$ include this as one of their methods of study. Bivariate correlational analysis was used to study the relationship between students' learning preferences and cGPA scores. As shown in Table 4, a significant relationship is observed between "practice past year examination papers" and cGPA. As such, it can be concluded that the most effective learning style that affected cGPA was practicing past year examination papers.

\begin{tabular}{|c|c|c|c|c|c|}
\hline \multirow[b]{2}{*}{ Learning preference } & \multicolumn{2}{|c|}{ Yes } & \multicolumn{2}{|c|}{ No } & \multirow[b]{2}{*}{$\begin{array}{c}\text { Significance } \\
\text { (2-tailed) }\end{array}$} \\
\hline & $\begin{array}{c}\text { Number of } \\
\text { students }\end{array}$ & $\begin{array}{c}\text { Mean cumulative } \\
\text { GPA }\end{array}$ & $\begin{array}{c}\text { Number of } \\
\text { students }\end{array}$ & $\begin{array}{c}\text { Mean cumulative } \\
\text { GPA }\end{array}$ & \\
\hline Discussion with friends & 112 & 3.087 & 32 & 3.097 & 0.925 \\
\hline Practice past year exam papers & 76 & 3.218 & 68 & 2.946 & 0.001 \\
\hline Learn by touching and exploring models & 57 & 3.09 & 87 & 3.032 & 0.086 \\
\hline Learn by watching videos or virtual learning & 57 & 3.177 & 87 & 3.032 & 0.355 \\
\hline Learn by drawing or using pictures in books & 74 & 3.09 & 70 & 3.091 & 0.965 \\
\hline
\end{tabular}

Table 4. Bivariate correlations among variables, mean, and standard deviations

\begin{tabular}{|c|c|c|c|c|c|c|c|c|}
\hline & Variables & 1 & 2 & 3 & 4 & 5 & 6 & 7 \\
\hline 1. & Cumulative GPA & - & & & & & & \\
\hline 2. & Listening and taking notes during lesson & 0.064 & - & & & & & \\
\hline 4. & Practice past year exam papers & $0.276^{* *}$ & 0.065 & 0.164 & - & & & \\
\hline 5. & Learn by touching and exploring models & 0.144 & $0.170^{*}$ & 0.159 & $0.197^{*}$ & - & & \\
\hline 6. & Learn by watching videos or virtual learning & 0.078 & 0.074 & $0.194^{*}$ & $0.168^{*}$ & $0.361^{*}$ & - & \\
\hline 7. & Learn by drawing or using pictures in books & -0.04 & -0.085 & $0.215^{* *}$ & 0.138 & 0.134 & $0.191^{*}$ & - \\
\hline & Mean & 3.090 & 0.90 & 0.78 & 0.53 & 0.40 & 0.40 & 0.51 \\
\hline & SD & 0.49 & 0.297 & 0.417 & 0.501 & 0.491 & 0.491 & 0.502 \\
\hline
\end{tabular}

SD = standard deviation. ${ }^{* *} \mathrm{p}<0.01$ level (2-tailed), ${ }^{*} \mathrm{p}<0.05$ level (2-tailed). 
The results of this study showed that using past year examination papers as one of the learning styles, improved cGPA significantly. Students who did not use this method of learning scored significantly lower cGPA scores. The results herein are in agreement with Felder [55] who reported that an association exists between students' learning preference, teaching style and academic performance. However, Mlambo [8] reported that there is no significant difference in academic performance among different learning preferences.

\section{Conclusion and Limitations}

The list of factors investigated in this study was not exhaustive. There are several other factors such as socioeconomic status, parents' education level, attendance, etc. that can influence academic performance. However, it can be concluded from this study that gender, nationality, involvement in ECA, intention to purse higher studies and learning preferences contributed to students' academic performance significantly. It is necessary for educators to understand the factors that may contribute to students' academic success so as to plan better classroom activities and strategies of teaching and learning [2]. Further research is necessary to explore other factors that may affect students' academic performance.

There are a number of limitations in this study that limit its generalizability. The study relied on self-report measures and the cGPA reported were obtained via a questionnaire. Our study used correlational analysis in certain aspects, which does not prove causal relations between variables. The sample population was selected from a single tertiary institution and hence there is limited generalizability of our results.

\section{References}

[1] Crosnoe, R., Johnson, M. K., \& Elder, G. H. (2004). School size and the interpersonal side of education: An examination of race/ethnicity and organizational context. Social Science Quarterly, 85(5), 1259-1274.

[2] Farooq, M.S., Chaudhry, A.H., Shafiq, M., and Berhanu, G. (2011). Factors affecting students' quality of academic performance: A case of secondary school level. Journal of Quality and Technology Management, 7, 1-14.

[3] Cambridge University Reporter. (2003). Indicators of academic performance. Available:

http://www.admin.cam.ac.uk/reporter/2002-03/weekly/5915/ [Accessed Feb. 12, 2014]

[4] Romer, D. (1993). Do students go to class? Should they? Journal of Economic Perspectives, 7(3), 167-174.

[5] Aripin, R., Mahmood, Z., Rohaizad, R., Yeop, U., \&Anuar, M. (2008). Students' learning styles and academic performance.22nd Annual SAS Malaysia Forum, 15th July 2008, Kuala Lumpur Convention Center, Kuala Lumpur, Malaysia.

[6] Haist, S. A., Wilson, J. F., Elam, C. L., Blue, A. V., \&Fosson, S. E. (2000). The effect of gender and age on medical school performance: An important interaction. Advances in Health SciencesEducation, 5(3), 197-205.

[7] Heinesen, E. (2010). Estimating class-size effects using withinschool variation in subject-specific classes. The Economic Journal, 120(545), 737-760.

[8] Mlambo, V. (2011). An analysis of some factors affecting student academic performance in an introductory biochemistry course at the University of the West Indies. Carribean Teaching Scholar, 1, 79-92.

[9] Ali, S., Haider, Z., Munir, F., Khan, H., and Ahmed, A. (2013). Factors Contributing to the Students Academic Performance: A
Case Study of Islamia University Sub-Campus. American Journal of Educational Research, 1, 283-289.

[10] Borde, S. F. (1998). Predictors of student academic performance in the introductory marketing course. Journal of Education for Business, 73, 302-307.

[11] Meece, J. L., \& Jones, M. G. (1996). Gender differences in motivation and strategy use in science: Are girls rote learners? Journal of Research in Science Teaching, 33, 393-406.

[12] Hedges, L., \& Newell, A. (1999). Changes in the Black-White gap in achievement scores. Sociology of Education, 72(2), 111-135.

[13] Alton-Lee, A., \&Praat, A. (2001). Explaining and addressing gender differences in the New Zealand compulsory school sector. Wellington: Ministry of Education. Available: http://www.educationcounts.govt.nz/_data/assets/pdf_file/0009/1 2141/Explaining_and_Addressing_Gender_Differences.pdf [Accessed Feb 18, 2014].

[14] Mullis, I. V. S., Martin, M. O., Gonzalez, E. J., \& Kennedy, A. M. (2003). PIRLS 2001 international report: IEA's study of reading literacy achievement in primary schools. Chestnut Hill, MA: Boston College.

[15] Woodfield, R., \& Earl-Novell, S. (2006). An assessment of the extent to which subject variation in relation to the award of first class degree between the arts and sciences can explain the 'gender gap’. British Journal of Sociology of Education, 27(3), 355-372.

[16] Portes, A. and Rumbaut, R.G. (2001) Legacies: The Story of the Immigrant Second Generation. New York: Russell Sage Foundation.

[17] Portes, A. and Rumbaut, R.G. (2005). "Introduction: The Second Generation and the Children of Immigrants Longitudinal Study" Ethnic and Racial Studies, 28(6), 983-999.

[18] Kroneberg, C. (2008). "Ethnic Communities and School Performance among the New' Second Generation in the United States: Testing the Theory of Segmented Assimilation.” The Annals of the American Academy of Political and Social Science, 620, 138-160.

[19] Yousef, D. A. (2011). Academic Performance of Business Students in Quantitative Courses: A Study in the Faculty of Business and Economics at the UAE University. Decision Sciences Journal of Innovative Education, 9, 255-267.

[20] Nasirudeen, A.M.A., Koh, W.N.J., Lau, L.C.A., Lim, L.S., and How, A.L. (2014). Acculturative stress among Asian international students in Singapore. Journal of International Students, 4, 363374.

[21] Chu, A. M., Yeh, E.K., Klein, N.A., Alexander, A.A., \& Miller, M.A. (1971). A study of Chinese students' adjustment in the U.S.A. Acta psychological Taiwanica, 13, 206-218.

[22] Dozier, S. B. (2001). Undocumented and documented international students. Community college review, 29(2), 43-54.

[23] Rienties, B., Beausaert, S., Grohnert, T., Niemantsverdriet, S., and Kommers, P. (2012). Understanding academic performance of international students: the role of ethnicity, academic and social integration. Higher Education, 63, 685-700.

[24] Desmedt, E., and Valcke, M. (2003). Learning style awareness: why would it work? Paper presented at the Proceedings of the Eighth Annual European Learning Styles Information Network Conference, University of Hull, UK.

[25] Norman, G.(2009). When will learning style go out of style? Advances in Health and Science Education, 14, 1-4.

[26] Coffield, F., Moseley, D., Hall, E., Ecclestone, K. (2004). Should we be using learning styles? What research has to say to practice. London: The Learning and Skills Research Centre.

[27] Fielding, M. (1994). Valuing difference in teachers and learners: building on Kolb's learning styles to develop a language of teaching and learning. Curriculum Journal, 5, 393-417.

[28] Lujan, H.L., and DiCarlo, S.E., 2006. First-year medical students prefer multiple learning styles. Advances in Physiology Education, 30, 13-16.

[29] Cuthbert, P.F. (2005) The student Learning Process: Learning Styles or learning approaches? Teach. Higher Education, 10, 235249.

[30] Alkhasawneh, I.M., Mrayyan, M.T., Docherty, C., Alashram, S., and Yousef, H.Y. (2008). Problem-based learning (PBL): assessing students' learning preferences using VARK. Nurse Education Today, 28, 572-579.

[31] Isman, C.A., and Gundogan, N.U. (2009). The influence of digit ratio on the gender difference in learning style preferences. Personality and Individual Differences, 46 (4), 424-427. 
[32] Meehan-Andrews, T.A. (2009). Teaching mode efficiency and learning preferences of first year nursing students. Nurse Education Today, 29, 24-32.

[33] Fleming, N.D., and Mills, C. (1992). Not another inventory, rather a catalyst for reflection. To Improve the Academy, 11, 137-149.

[34] Hruska-Riechmann, S., and Grasha, A.F. (1982). The GrashaReichmann student learning style scales. In: Keef, J. (Ed.), Student Learning Styles and Brain Behaviour. National Association of Secondary School Principals, Reston, Va, pp. 81-86.

[35] Holloway, J.H. (1999). Research Link / Extracurricular Activities: The Path to Academic Success? Understanding Youth Culture, 57, 87-88.

[36] Silliker, S., \& Quirk, J. (1997). The effect of extracurricular activity participation on the academic performance of male and female high students.The School Counselor, 44, 288-293.

[37] Gerber, S. (1996). Extracurricular activities and academic achievement.Journal of Research and Development in Education, 30(1), 42-50.

[38] Marsh, H. W., \&Kleitman, S. (2002). Extracurricular activities: The good, the bad, and the nonlinear [Electronic version]. Harvard Educational Review, 72, 464-512.

[39] Bandura, A. (1977). Self-efficacy: Toward a unifying theory of behavioral change. Psychological Review, 84, 191-215.

[40] Zimmerman, B., Bandura, A. \& Martinez-Pons, M. (1992). Selfmotivation for academic attainment: The role of self-efficacy beliefs and personal goal setting. American Educational Research Journal, 29, 663-676.

[41] Fraenkel, J.R., \&Wallen, N.E. (1996). How to design and evaluate research in education (3rd Ed.). New York: McGraw-Hill.

[42] Polit, D.F. and Beck, C.T. (2006). The content validity index: Are you sure you know what's being reported? Critique and recommendations. Research in Nursing \& Health, 29, 489-497.

[43] Kathuri, N. J, and Palls, A. D. (1993). Introduction to educational research. Egerton University Education Book series.

[44] Sutherland, W.J., Spiegelhalter, D. \&Burgman, M.A. (2013). Twenty tips for interpreting scientific claims. Nature, 503, 335337.
[45] Cohen, J. (1988). Statistical power analysis for the behavioral sciences (2nd ed.). Hillsdale, NJ: Lawrence Earlbaum Associates.

[46] Lao, R. C. (1980). Differential Factors Affecting Male and Female Academic Performance in High School, The Journal of Psychology, 104, 119-127.

[47] Leonard, D. K. and Jiang, J. (1999) Gender Bias and the College Predictors of the SATs: A Cry of Despair, Research in Higher Education, 40, 375-407.

[48] Ceballo, R., McLoyd, V., \&Toyokawa, T. (2004). The influence of neighbourhood quality on adolescents' educational values and school efforts. Journal of Adolescent Research, 19, 716-739.

[49] Wainer, H. and Steinberg, L. S. (1992) Sex Differences in Performance on the Mathematics Section of the Scholastic Aptitude Test: A Bidirectional Validity Study, Harvard Educational Review, 62, 323-336.

[50] Newman-Ford, L., Lloyd, S., \& Thomas, S. (2009). An investigation in the effects of gender, prior academic achievement, place of residence, age and attendance on first-year undergraduate attainment. Journal of Applied Research in Higher Education, 1, 13-28.

[51] Richardson, J.T.E. (1994). Mature students in higher education: academic performance and intellectual ability. Higher Education 28.Kluwer Academic Publishers. The Netherlands.

[52] Fredricks, J.A., \& Eccles, J.S. (2006). Is extracurricular participation associated with beneficial outcomes? Concurrent and longitudinal relations. Developmental Psychology, 42, 698-713.

[53] Gardner, M., Roth, J., \& Brooks-Gunn, 1. (2008). Adolescents' participation in organized activities and developmental success 2 and 8 years after high school: Do sponsorship, duration, and intensity matter? Developmental Psychology, 44, 814-830.

[54] Bandura, A. \&Schunk, D. (1981). Cultivating competence, selfefficacy, and intrinsic interest through proximal self-motivation. Journal of Personality and Social Psychology, 41, 586-598.

[55] Felder, R.M. (1993). "Reaching the Second Tier: Learning and Teaching Styles in College Science Education," J. Coll. Sci. Teaching, 23, 286-290. 